\title{
Keratoacanthoma of the conjunctiva in a young patient
}

\section{Ceratoacantoma da conjuntiva em um paciente jovem}

\author{
Gokhan Ozge ${ }^{1}$, Yusuf Uysal ${ }^{1}$, Osman Melih Ceylan ${ }^{2}$, Onder Onguru³${ }^{3}$, Fatih Mehmet Mutlu ${ }^{1}$
}

\begin{abstract}
Keratoacanthomas rarely occur in the conjunctiva. We report a case of a 24-year-old man with a rapidly growing conjunctival mass. The tumor was excised with a safety margin to exclude squamous cell carcinoma and was histopathologically diagnosed as a keratoacanthoma. There has been no recurrence over 2 years of follow-up. To the best of our knowledge, he is the youngest patient to be diagnosed with conjunctival keratoacanthoma who had no known risk factors such as skin disorders, trauma, surgery, or infection. In similar cases, we recommend complete early surgical excision and careful follow-up to exclude malignancy.
\end{abstract}

Keywords: Keratoacanthoma/diagnosis; Keratoacanthoma/surgery; Carcinoma squamous cell; Diagnosis, differential; Case reports

\section{RESUMO}

Ceratoacantoma raramente ocorre na conjuntiva. Nós relatamos o caso de um homem de 24 anos de idade, com uma massa conjuntival de rápido crescimento. 0 tumor foi retirado com uma margem de segurança para excluir carcinoma de células escamosas. Elefoidiagnosticado histopatologicamente como sendo ceratoacantoma. Não houve recidiva em dois anos de seguimento. Ele é o paciente mais jovem com ceratoacantoma conjuntival que não tinham fatores de risco conhecidos como doenças de pele a ser descrito. Em casos semelhantes, recomendamos excisão cirúrgica precoce completo e um acompanhamento cuidadoso para excluir malignidade.

Descritores: Ceratoacantoma/diagnóstico; Ceratoacantoma/cirurgia; Carcinoma de células escamosas; Diagnóstico diferencial; Relatos de casos

\section{INTRODUCTION}

Keratoacanthomas (KAs) are common low-grade tumors that originate in the pilosebaceous glands of hair follicles ${ }^{(1)}$ and are considered to be a form of squamous cell carcinoma (SCC) ${ }^{(1)}$. Pathologists often label KAs as "well-differentiated squamous cell carcinoma, keratoacanthoma variant," because approximately $6 \%$ of KAs manifest as SCC when left untreated ${ }^{(2)}$. KAs are characterized by rapid growth over a few weeks, followed by spontaneous regression over 4-6 months.

KAs are commonly found on sun-exposed areas, such as the face, neck, and dorsum of the upper extremities ${ }^{(3)}$; however, KA of the conjunctiva is rare. We report here a case of conjunctival KA that was surgically treated in a young patient.

\section{CASE REPORT}

A 23-year-old man presented with a 3-month history of redness, foreign body sensation, and conjunctival mass that grew rapidly in his left eye. His visual acuity was 20/20 and fundoscopic exam was normal in both eyes. In the left eye, a white, nodular mass was noted on the nasal conjunctiva adjacent to the limbus. The conjunctival mass was $4 \times 5 \mathrm{~mm}$ in size, had a hyperkeratotic surface, and was surrounded by dilated vessels (Figure 1). No palpable lymphadenopathy was observed. The patient had no history of injury, previous ophthalmic surgery, or human papilloma virus infection, and was human ımmunodeficiency virus (HIV) negative.

The lesion was totally excised under local anesthesia, and cryotherapy was applied to the surgical margins. Subsequent histopathologic examination under low-power microscopy showed that the tumoral lesion had overhanging edges and a hemispheric-like shape without a keratin plug. The lesion was composed of deeply elongated, enlarged, and merged solid islands of large, pale squamous cells with little keratinization (Figure 2 A). The squamous cells showed moderate to marked atypia, and mitotic figures were easily found (Figure 2 B). Additionally, mild inflammatory cell infiltration was observed. From these findings, conjunctival KA was diagnosed. The resected site on the conjunctiva healed well without complications. No recurrence was detected over 2 years of follow-up.

\section{Discussion}

KAs are commonly found on sun-exposed areas of the skin. The first case of conjunctival KA was described by Freeman et al.(4), and only a few cases have been described to date ${ }^{(5-7)}$. Most of the documented cases have been found on the temporal bulbar conjunctiva within the palpebral aperture and adjacent to the limbus. However, in our patient, the KA formed on the nasal conjunctiva, which was similar to cases reported by Perdigao et al. ${ }^{(6)}$ and Chowdhury et al. ${ }^{(8)}$. A male predominance was observed in previously reported cases, and our patient was also male.

Cutaneous KAs are characterized by an initial period of rapid growth followed by spontaneous regression, usually within 6 months. However, the natural history of conjunctival KA is unclear because of timely resection. In addition, our patient's symptoms, including foreign body sensation, redness, and the rapidly growing mass had been ongoing for 3 months, and early surgery was performed in order differential diagnose with SCC.
Submitted for publication: February 19, 2015

Accepted for publication: July 21, 2015

Department of Ophthalmology, Gulhane Military Medical Academy and Faculty of Medicine, Ankara, Turkey.

2 Department of Ophthalmology, Medicalpark Hospital, Ankara, Turkey.

${ }^{3}$ Department of pathology, Gulhane Military Medical Academy and Faculty of Medicine, Ankara, Turkey.
Funding: No specific financial support was available for this study.

Disclosure of potential conflicts of interest: None of the authors have any potential conflict of interest to disclose.

Corresponding author: Gokhan Ozge. Department of Ophthalmology - Gulhane Military Medical School - Ankara, Turkey, 06010 - E-mail: dr_gozge@yahoo.com 


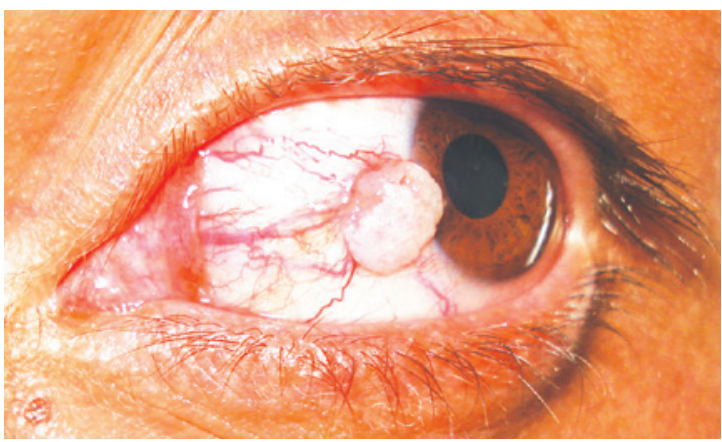

Figure 1. White, nodular mass on the nasal conjunctiva adjacent to the limbus. The mass was $4 \times 5 \mathrm{~mm}$ in size and surrounded by dilated vessels.
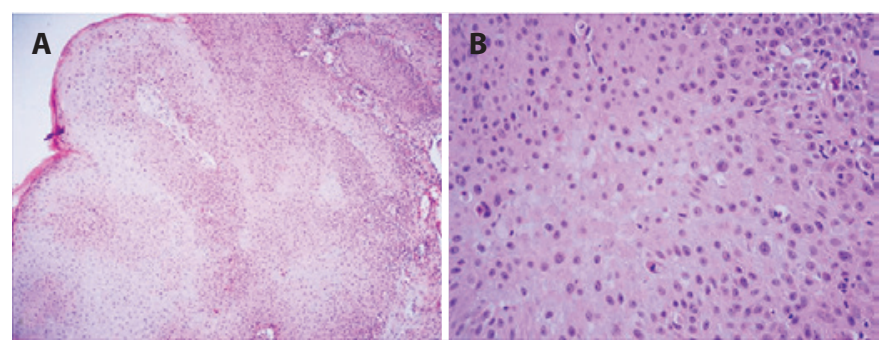

Figure 2. (A) The lesion was composed of deeply elongated, enlarged, and merged solid islands of large, pale squamous cells (hematoxylin-eosin $\times 100$ ). (B) The squamous cells showed moderate to marked atypia and frequent mitosis (hematoxylin-eosin $\times 200$ ).

Conjunctival SCC is more common in elderly patients, but may occur earlier in patients with xeroderma pigmentosum or acquired immune deficiency syndrome (AIDS) ${ }^{(9)}$. Differentiation between SCC and KA can be challenging. KAs can easily be mistaken for SCC as their clinical presentation and histopathologic findings are very similar. Some authors regard KAs as a variant of SCC. Grossniklaus et al. reported cases of conjunctival KA with invasive features ${ }^{(10)}$, describing a case with a rapidly growing limbal lesion that was excised after 3 weeks with histological evidence of invasion. Subsequent rapid recurrence was observed in their patient, with intraocular invasion requiring enucleation, and surgical removal was justified to prevent possible eventual malignancy, as well as the difficulty of clinically differentiating this lesion from SCC. In our patient, we excised the lesion surgically with cryotherapy application to the limbus and conjunctival margins. As mentioned earlier, it may be difficult to histopatho- logically differentiate KA from SCC, particularly when lesions are incompletely excised. KAs are hemispheric-like, symmetric lesions with both exophytic and endophytic growth. They usually present with a keratin-filled central crater with overhanging epidermal edges and are composed of keratinocyte proliferations with large glassy, eosinophilic cytoplasm. The keratinocytes in KA show mild-to-moderate nuclear atypia. Mild-to-moderate inflammatory infiltrate at the base of the lesion may be present. SCC shows invasion of the dermis or subepithelial tissue, with irregular islands of squamous cells. Although keratinized and squamous pearls are abundant in well-differentiated SCC, they are absent in poorly differentiated tumors. Dermal/subepithelial inflammatory infiltrate may be observed. Histopathologic examination showing overhanging edges and a hemispheric-like lesion with marked atypical squamous cells suggest KA. The rapid growth of the lesion in our young patient also supports this diagnosis. Normal conjunctival epithelium was observed at the resected edges.

In literature, KA is typically reported in middle-aged and elderly patients, except for a 17-year-old patient with xeroderma pigmentosum, which was probably responsible for the younger age of onset ${ }^{(8)}$. However, we report a 23-year-old patient who had no history of trauma, surgery, infection, or skin disorders. To the best of our knowledge, he is the youngest patient to be reported with KA who had no risk factors for the disease.

In conclusion, both KA and SCC are possible in young patients, and we recommend early excision of suspected conjunctival KA for differential diagnosis with SCC. Careful follow-up is important for all patients with conjunctival KA after complete excision.

\section{REFERENCES}

1. Manstein $\mathrm{CH}$, Frauenhoffer $\mathrm{CJ}$, Besden JE. Keratoacanthoma: is it a real entity? Ann Plast Surg. 1998;40(5):469-72

2. Weedon DD, Malo J, Brooks D, Williason R. Squamous cell carcinoma arising in keratoacanthoma: a neglected phenomenon in the elderly. Am J Dermatopathol. 2010;32(5):423-6.

3. Kossard S, Tan KB, Choy C. Keratoacanthoma and infundibulocystic squamous cell carcinoma. Am J Dermatopathol. 2008;30(2):127-34.

4. Freeman RG, Cloud TM, Knox JM. Keratoacanthoma of the conjunctiva. A case report. Arch Ophthalmol. 1961;65:817-9.

5. Hughes EH, Intzedy L, Dick AD, Tole DM. Keratoacanthoma of the conjunctiva. Eye (Lond). 2003;17(6):781-2.

6. Perdigao FB, Pierre-Filho PT, Natalino RJ, Caldato R, Torigoe M, Cintra ML. Conjunctival keratoacanthoma. Rev Hosp Clin Fac Med Sao Paulo. 2004;59(3):135-7.

7. Oellers P, Karp CL, Shah RR, Winnick M, Matthews J, Dubovy S. Conjunctival keratoacanthoma. Br J Ophthalmol. 2014;98(2):275-6, 285

8. Chowdhury RK, Padhi T, Das GS. Keratoacanthoma of the conjunctiva complicating xeroderma pigmentosum. Indian J Dermatol Venereol Leprol. 2005;71(6):430-1.

9. Muccioli C, Belfort R Jr, Burnier M, Rao N. Squamous cell carcinoma of the conjunctiva in a patient with the acquired immunodeficiency syndrome. Am J Ophthalmol. 1996;121(1):94-6.

10. Grossniklaus HE, Martin DF, Solomon AR. Invasive conjunctival tumor with keratoacanthoma features. Am J Ophthalmol. 1990;109(6):736-8. 